Dept. of Microbiology,

Fac. Vet. Med., Kafr El-Sheikh, Tanta University.

\title{
PREVALENCE AND ETIOLOGY OF SUBCLINICAL MASTITIS IN DAIRY EWES AT FAYOUM GOVERNORATE, EGYPT
}

(With 6 Tables)

\author{
By \\ A.A. MOAWAD and S.A. OSMAN* \\ * Dept. of Animal Medicine, Fac. Vet. Med., Kafr El-Sheikh, Tanta University.
}

(Received at 27/7/2005)

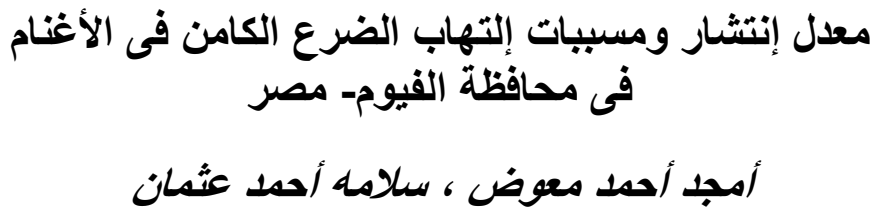

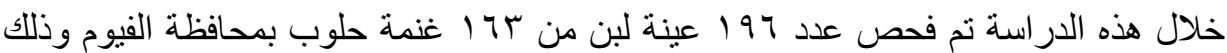

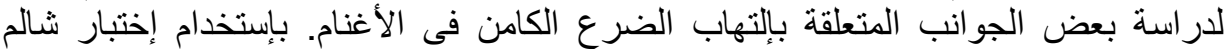

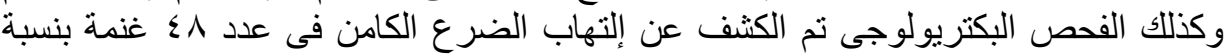

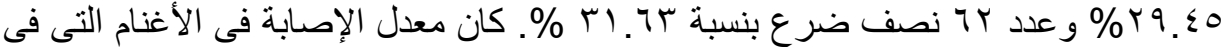

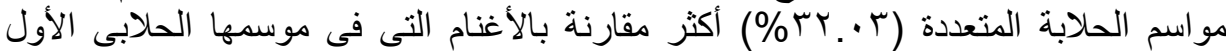

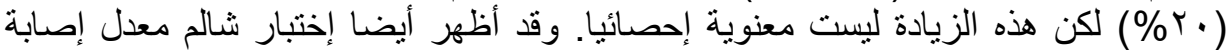

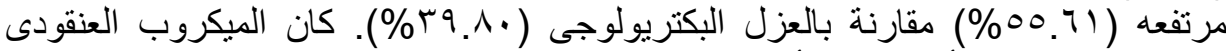

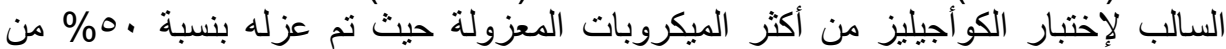

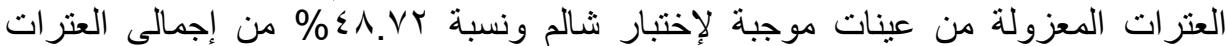

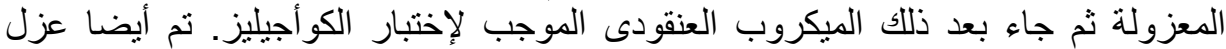

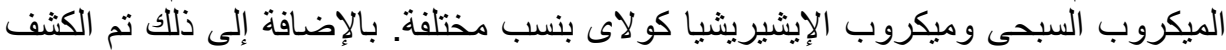

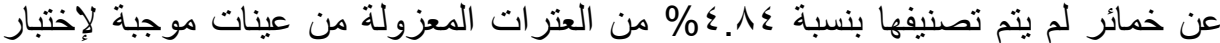

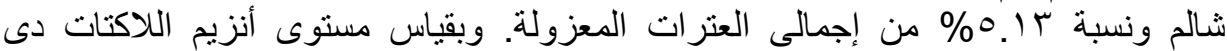

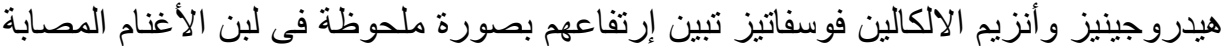

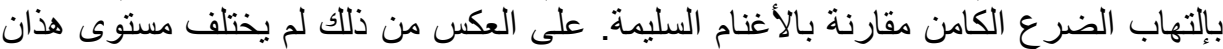
الإنزيمان فى مصل الدم للأغنام المريضة بالإنام السليمة.

\section{SUMMARY}

In Fayoum Governorate, a total of 196 milk samples were collected aseptically from apparently healthy functioning glands of 163 dairy ewes to study subclinical mastitis (SCM) in dairy ewes. According to the 
definition of SCM the only sample that showed California Mastitis Test (CMT) and bacteriology positive results was considered to have subclinical mastitis, the prevalence of SCM was $29.45 \%$ in regard to ewes and $31.63 \%$ in regard to glands. Subclinical mastitis was higher in multiparous ewes $(32.03 \%)$ than primiparous ones $(20.0 \%)$, but this increase is not statistically significant. CMT was useful as a screening test in ovine species to identify infected animals, keeping in mind that the test showed higher prevalence rate of subclinical mastitis than bacteriological culture (55.61\% compared with $39.80 \%$ ). Staphylococci were the most common bacteria detected (73.08\% isolates), where coagulase-negative staphylococci (CNS) were detected in 50\% of CMT positive samples isolates and in $48.72 \%$ of the total bacterial isolates and Staphylococcus aureus ( $S$. aureus) was isolated in a percentage of $30.65 \%$ only from CMT positive samples followed by Streptococcus agalactiae (S. agalactiae) in $9.68 \%$ of CMT positive samples isolate and lastly Escherichia coli (E. coli) in $4.84 \%$ of CMT positive samples isolate and in $14.10 \%$ of the total bacterial isolates. Yeast was also detected in $4.84 \%$ of the CMT positive samples isolate and in $5.13 \%$ of the total isolates. Enzymatic activities of lactate dehydrogenase (LDH) and alkaline phosphatase (ALP) proved to be good indicator for intramammary infection in ewes, where, enzymatic activities of LDH and ALP were significantly higher $(p<0.05)$ in milk from subclinically mastitic ewes compared to milk from healthy ones. On the other hand, there were no significant alterations recorded in the levels of serum LDH and ALP of subclinically mastitic ewes compared to healthy ones.

Key words: Mastitis, subclinical mastitis, dairy ewes, milk

\section{INTRODUCTION}

Mastitis is one of the most serious health and economic problems in all dairy sheep flocks all over the major sheep breeding countries (Fthenakis and Jones, 1990 and Kirk and Glenn, 1996). Although ovine clinical mastitis is typically gangrenous and causes death, the more important economically is subclinical mastitis due to its high prevalence rate (Marco, 1994) and association with decrease in milk production in addition to growth retardation and high mortality rate among lambs in suckling ewes (Gross et al., 1978; Waston and Buswell, 1984; McCarthy et al., 1988; Fthenakis and Jones, 1990; Mavrogenis et al., 1995; Dario et al., 1996; Peris et al., 1996 and Saratsis et al., 1999). 
Intramammary infections (IMI) in dairy small ruminants are mainly of bacterial origin by either contagious pathogens (Staphylococcus aureus and Streptococcus agalactiae) or environmental pathogens (Escherichia coli, Pseudomonas aeruginosa, Streptococcus uberis and coagulase-negative staphylococci) (Radostits et al., 2000 and Bergonier et al., 2003). Staphylococci are the main etiological agents of small ruminants intramammary infections (IMI), where, Staphylococcus aureus is the most common pathogen isolated in clinical cases and coagulase-negative staphylococci (CNS) are the most prevalent in subclinical cases (Fthenakis, 1994; Lafi et al., 1998 and Bergonier et al., 2003).

Diagnosis of subclinical mastitis is commonly based on cytological examination as well as biochemical changes in milk but confirmation must be based on bacteriological examination (Keisler et al., 1992 and Radostits et al., 2000)

The aim of the present work was directed to determine the prevalence of subclinical mastitis in dairy ewes and the microbial agents associated with such infections. In addition, to study the changes occurring in the levels of lactate dehydrogenase (LDH) and alkaline phosphatase (ALP) in the milk and blood as a result of subclinical mastitis in this species.

\section{MATERIALS and METHODS}

\section{Animals:}

In this study, 163 native dairy ewes (Balady breed) from 17 flocks belonging to Fayoum Governorate, Egypt were used to study some aspects concerning subclinical mastitis in this species. Ewes selected for this investigation were apparently healthy, free from any signs of clinical mastitis and other palpable udder lesions. The system of milking in these flocks was hand milking.

\section{Sampling Procedure:}

A total of 196 milk samples were collected aseptically from apparently healthy functioning glands of 163 dairy ewes according to the method described by Al-Majali and Jawabreh (2003) and Batavani et al. (2003) as follows: ewes were restrained in a sitting position and the teat end of each udder half was scrubbed thoroughly using cotton wool soaked in $70 \%$ ethyl alcohol. The first three streams were discarded, the teat orifice was disinfected again as described and $10 \mathrm{ml}$ milk sample was taken from each gland in a sterile tube and examined for any macroscopic abnormalities by visual inspection and strip cup method. In 
addition, jugular blood samples $(10 \mathrm{ml})$ were taken by vein puncture form each animal into dry centrifuge tubes without anticoagulant and allowed to clot. All samples were kept at $4{ }^{\circ} \mathrm{C}$ during transportation and delivered to the laboratory for examination within 2 to 4 hours after collection. Serum was separated after centrifugation and stored at $-20^{\circ} \mathrm{C}$ until thawed for analysis. All milk and blood samples were collected in mid-lactation ( $2^{\text {nd }}$ week after lambing until $10^{\text {th }}$ week postpartum)

\section{California Mastitis Test (CMT):}

CMT was carried out for all milk samples, using the method described by Schalm et al. (1971). According to the visible reactions, the results were classified in five degrees of reaction scores: $0=$ negative, trace, $1=$ weak positive, $2=$ distinct positive and $3=$ strong positive.

\section{Bacteriological Examinations:}

All milk samples $(10 \mu \mathrm{l}$ from each) were inoculated onto the surface of 5\% sheep blood and MacConkey agar plates. All plates were incubated aerobically at $37^{\circ} \mathrm{C}$ and examined for growth at 24 hours. Hemolysis and colonial morphology were recorded after 24 - 48 hours. Gram positive cocci with catalase positive and oxidase negative reaction were subjected to coagulase test by tube method (Langlois et al., 1990). Other bacterial isolates were examined for their staining affinity, morphological, cultural and their biochemical characters according to the standard methods described by Cruickshank et al. (1975).

\section{CAMP test:}

Staphylococcus aureus was streaked across the center of sheep blood agar. A streak of the suspected Streptococcus is made at right angle too and taken within $1-1.5 \mathrm{~mm}$ of the staphylococcal streak. Plate incubated at $37^{\circ} \mathrm{C}$ for $18-24$ hours. An arrow head formed at junction between streaks means positive CAMP test (Cruickshank et al., 1975).

\section{Sodium hippurate hydrolysis test:}

Used for confirmation of Streptococcus agalactiae. 1\% aqueous solution of sodium hippurate that inoculated with the suspected microorganism was incubated at $37^{\circ} \mathrm{C}$ for two hours, then $0.2 \mathrm{ml}$ of a ninhydrin solution was added. The positive reaction is given by a deep purple color developed after 10 minutes.

\section{Enzyme Analysis:}

All milk samples were centrifuged at 3000 r. p. m. for 10 minutes and defattened milk was prepared. LDH and ALP activities were measured in blood serum and defattened milk according to the method described by Bergmeyer (1974). 


\section{Statistical analysis:}

Chi-square and student ' $t$ test were carried to the obtained data according to Snedecor and Cochran (1980). Probabilities less than 0.05 were considered significant.

\section{RESULTS}

In the present study, out of the examined 196 milk samples which collected aseptically from apparently healthy functioning glands of 163 dairy ewes, Positive CMT was recorded in 109 (55.61\%) of the examined glands and in $88(53.98 \%)$ of the examined ewes. Bacteria and yeast were isolated from $78(39.79 \%)$ of the examined udder halves and $59(36.20 \%)$ of the examined ewes. So, using the definition of SCM as the presence of both bacteriologically positive and CMT positive results, $62(31.63 \%)$ of the examined glands and $48(29.45 \%)$ of the examined ewes were affected (Table 1 and 2).

Table 1: Results of CMT and bacteriological culture on examined milk samples $(\mathrm{N}=196)$.

\begin{tabular}{|l|c|c|c|c|c|c|}
\hline \multirow{2}{*}{ Bacteriology } & \multicolumn{2}{|c|}{ CMT + ve } & \multicolumn{2}{c|}{ CMT - ve } & \multicolumn{2}{c|}{ Total } \\
\cline { 2 - 7 } & No. & $\%$ & No. & $\%$ & No. & $\%$ \\
CMT & & & & & & \\
\hline CMT + ve & 62 & 56.88 & 47 & 43.12 & 109 & 55.61 \\
CMT - ve & 16 & 18.39 & 71 & 81.61 & 87 & 44.39 \\
Total & 78 & 39.80 & 118 & 60.20 & 196 & 100 \\
\hline
\end{tabular}

Samples that gave score 1 were considered positive for CMT

Table 2: Results of CMT and bacteriological culture on examined ewes $(\mathrm{N}=163)$.

\begin{tabular}{|l|c|c|c|c|c|c|}
\hline \multirow{2}{*}{ Bacteriology } & \multicolumn{2}{|c|}{ CMT + ve } & \multicolumn{2}{c|}{ CMT - ve } & \multicolumn{2}{c|}{ Total } \\
\cline { 2 - 7 } & No. & $\%$ & No. & $\%$ & No. & $\%$ \\
CMT & & & & & & \\
\hline CMT + ve & 48 & 54.54 & 40 & 45.45 & 88 & 53.99 \\
CMT - ve & 11 & 14.67 & 64 & 85.33 & 75 & 46.01 \\
Total & 59 & 36.20 & 104 & 63.80 & 163 & 100 \\
\hline
\end{tabular}

Subclinical mastitis was higher in multiparous ewes $(32.03 \%)$ than primiparous ones $(20.0 \%)$, but this increase is not statistically significant as shown in Table 3. 
Table 3: Prevalence of subclinical mastitis in relation to parity status.

\begin{tabular}{|l|c|c|c|}
\hline Animal status & $\begin{array}{c}\text { No. of examined } \\
\text { ewes }\end{array}$ & $\begin{array}{c}\text { No. of infected } \\
\text { ewes }\end{array}$ & $\%$ \\
\hline Primiparous ewes & 35 & 7 & 20.0 \\
Multiparous ewes & 128 & 41 & 32.03 \\
\hline Total & 163 & 48 & 29.45 \\
\hline
\end{tabular}

Frequent distribution of the microbial isolates detected in bacteriology positive milk samples in dairy ewes as shown in Table 4 were: CNS in $48.72 \%$ of the total isolates $50 \%$ of them from CMT positive samples, Staphylococcus aureus (S. aureus) and Streptococcus agalactiae ( $S$. agalactiae) were detected only from CMT positive samples in $30.65 \%$ and $7.69 \%$ respectively, Escherichia coli (E. coli) in $14.10 \%$ of the total isolates $4.84 \%$ of them from CMT positive samples and unidentified yeast species in $5.13 \%$ of the total isolates, $4.84 \%$ of them from CMT positive samples..

Table 4: Frequency of bacterial isolates in milk obtained from udder halves which demonstrated positive and negative reactions to the CMT.

\begin{tabular}{|l|c|c|c|c|c|c|}
\hline \multirow{2}{*}{ Microorganisms } & \multicolumn{2}{|c|}{$\begin{array}{c}\text { CMT + ve samples } \\
(\mathrm{N}=62)\end{array}$} & \multicolumn{2}{c|}{$\begin{array}{c}\text { CMT - ve samples } \\
(\mathrm{N}=16)\end{array}$} & \multicolumn{2}{c|}{$\begin{array}{c}\text { Total isolates } \\
(\mathrm{N}=78)\end{array}$} \\
\cline { 2 - 7 } & No. & $\%$ & No. & $\%$ & No. & $\%$ \\
\hline CNS & 31 & 50.0 & 7 & 43.75 & 38 & 48.72 \\
S. aureus & 19 & 30.64 & 0 & 0.0 & 19 & 24.36 \\
S. agalactiae & 6 & 9.68 & 0 & 0.0 & 6 & 7.69 \\
E. coli & 3 & 4.84 & 8 & 50.0 & 11 & 14.10 \\
Unidentified yeast & 3 & 4.84 & 1 & 6.25 & 4 & 5.13 \\
\hline
\end{tabular}

Staphylococci (CNS and S. aureus) were the most common bacteria detected (73.08\%).

Enzymatic activities of LDH and ALP in milk and serum of healthy and subclinically mastitic ewes are shown in Tables 5 and 6.

Table 5: Mean \pm SE levels of LDH and ALP in examined milk samples (IU/I).

\begin{tabular}{|l|c|c|}
\hline & $\begin{array}{c}\text { Normal milk } \\
(\mathrm{N}=20)\end{array}$ & $\begin{array}{c}\text { Subclinical mastitic milk } \\
(\mathrm{N}=30)\end{array}$ \\
\hline LDH & $610.11 \pm 17.38$ & $886 \pm 41^{*}$ \\
ALP & $100.09 \pm 15.17$ & $143 \pm 11^{*}$ \\
\hline
\end{tabular}

* = Significant at $P<0.05$ vs. controls. 
Table 6: Mean \pm SE levels of $\mathrm{LDH}$ and ALP in examined serum samples (IU/ I).

\begin{tabular}{|l|c|c|}
\hline & Serum from healthy ewes & Serum from infected ewes \\
\hline LDH & $730.11 \pm 100.04$ & $766 \pm 89.1$ \\
ALP & $149.15 \pm 118.70$ & $136 \pm 17.1$ \\
\hline
\end{tabular}

There was no significant differences in the levels of LDH and ALP in blood serum.

\section{DISCUSSION}

Mammary glands without clinical abnormalities and giving apparently normal milk, but with bacteriological counts higher than 200 $\mathrm{CFU} / \mathrm{ml}$ of the same type of colonies and with positive CMT were considered to have subclinical mastitis (Stefanakis et al., 1995).

In this study, the prevalence of subclinical mastitis in native dairy ewes in regards to ewes was $29.45 \%$. Similar results were reported previously by Kirk et al. (1996) who recorded a prevalence rate of $29 \%$. Higher prevalence was reported by Winkler and Gootwine (1989) who recorded prevalence rate of $55 \%$. Lower prevalence was reported by Ahmed et al. (1992) and Al-Majali and Jawabreh (2003) who reported prevalence rates of $25 \%$ and $18.3 \%$ respectively.

Concerning the prevalence of subclinical mastitis in regards to glands, it was $31.63 \%$. Lower prevalence was reported previously by Kirk et al. (1996) and Al-Majali and Jawabreh (2003) who recorded prevalence rates of $13.1 \%$ and $10.4 \%$ respectively. In contrast, higher prevalence rates were reported by Ariznabarreta et al. (2002) and Batavani et al. (2003) who reported prevalence rates ranged from 39 to $41 \%$. These variations in the disease prevalence may be attributed to the differences in the husbandry, management, nutrition, size of flock, breed, parity of the lamb, lactation period, season and the used diagnostic criteria (McCarthy et al., 1988; Tietze et al., 1993; Fthenakis, 1994; Stefanakis et al., 1995; Dario et al., 1996 and Lafi et al., 1998).

In this study, Subclinical mastitis was higher in multiparous ewes $(32.03 \%)$ than primiparous ones $(20.0 \%)$, but this increase is not statistically significant. Similar observations were recorded previously by Watkins et al. (1991) and Lafi et al. (1998). This may be attributed to the cumulative stress on the mammary tissues or to increased prevalence of infection and permanent glandular damage from previous infections (Lafi et al., 1998).

CMT test showed higher prevalence rate of subclinical mastitis than bacteriological culture (55.61\% compared with $39.80 \%)$. This may 
be explained on the fact that CMT has been standardized for cow's milk so, it is most accurate in this species (Schalm et al., 1971).

CMT was useful as a screening test in ovine species to identify animals for culture, keeping in mind that certain selected animals will be culture negative (false positive results). These false positive results may be attributed to the presence of non infectious factors that can affect milk somatic cell count as diurnal variation of SCC (up to $40 \%$ increasing in evening milking than that obtained in morning milking) and the stage of lactation (Fthenakis, 1996). In addition, ewes tended to have a higher cell counts, nuclear fragments, cytoplasmic particles and fat content in normal milk (Green, 1984; Maisi et al, 1987; Fthenakis and Jones, 1990 and Donovan et al., 1992).

Staphylococci were the most common bacteria detected in this study representing a total percentage of $73.08 \%$ of positive cultures, with CNS representing $48.72 \%$ from these isolates. Similar findings were reported in previous studies by De la Cruz et al. (1994); GonzalezRodriguez et al. (1995); Las Heras et al. (1999); Menzies and Ramanoon, (2001); Vieira-da-Motto et al. (2001); Ariznabarreta et al. (2002); McDougall et al. (2002); Bergonier and Berthelot (2003) and Bergonier et al. (2003) who recorded that CNS were the most prevalent pathogens of the mammary gland in sheep. The highest infection rate by CNS may be explained by the fact that CNS is encountered in the environment as an environmental pathogen. So; it is able to colonize the skin of animal, introduced from the skin to the gland by the process of suckling or during milking via teat canal causing minor mastitis in ewes. The CNS have been reported to produce virulence factors hence clinical infections are being increasingly associated with the organisms (Nobel, 1992). The virulence factors may be responsible for the cases of clinical and subclinical mastitis due to CNS (Jarp, 1991; Devriese et al., 1994 and Lafi et al., 1994). Staphylococcus epidermidis has been described as a potential pathogen for the mammary gland; either increasing SCC or causing persistent infections. In addition, S. epidermidis is commonly considered to be a mastitis pathogen of low virulence (Fthenakis and Jones, 1990 and Burriel, 1997).

Teat dipping which is an integral part of mastitis control programs in dairy flocks was not practiced in any one of the flocks under study. So, the increasing in the environmental and opportunistic pathogens is mainly related to poor conditions of environmental hygiene and/or decreased defenses of the mammary gland (Moroni and Cuccuru, 2001 and Albenzio et al., 2002). Similar results were observed 
previously by Harmon and Langlois (1995) who recorded that the prevalence of Staphylococcus spp. appeared to be influenced by teat dipping. Furthermore, Hogan et al. (1987) found that S. epidermidis was the predominant staphylococci for lactating dairy cows when teat dipping was not practiced.

Staphylococcus aureus was the second most common pathogen isolated in a percentage of $30.64 \%$ from CMT positive samples isolates and in percentage of $24.36 \%$ from the total bacterial isolates. The high persistence of mastitis due to $S$. aureus is related to its capacity to produce exo-polysaccharides ("slime"), which form a protective barrier that restricts the efficiency of both the immune responses and chemotherapy (Baselga et al., 1994).

The percentage of Streptococcus agalactiae in this study was 9.68\% in CMT positive samples isolate and in a percentage of $7.69 \%$ from the total bacterial isolates, in accordance with the results reported previously by Gnozalez-Rodriguez et al. (1995) who recorded a percentage ranged from $8.2 \%$ to $18 \%$.

Escherichia coli was detected in a percentage of $4.84 \%$ of CMT positive samples isolates and in a percentage of $14.10 \%$ from the total bacterial isolates. Similar results were recorded previously by Maisi et al. (1987) and Lafi et al. (1994).

In addition to the above mentioned bacteria, yeast was detected in $4.84 \%$ of the CMT positive samples isolate and in $5.13 \%$ from the total isolates. These results are in agreement with the results previously reported by Gonzalez-Rodriguez et al. (1995) who isolated yeast from ewes having subclinical mastitis.

Concerning the use of enzymatic changes that occurred in milk as an assisting tool in diagnosing of subclinical mastitis, LDH and ALP have been used in cattle to diagnose udder infections (Kovac and Beseda, 1975; Michel, 1979; Kitchen, 1981; Deianov, 1983 and Pednekar et al., 1992). In this study measuring of the LDH and ALP revealed that the mean activity of LDH and ALP were significantly higher $(p<0.05)$ in milk from subclinically mastitic milk compared to those of normal milk. Similar result was reported previously by Batavani et al. (2003). Higher LDH activity in milk of subclinical mastitic ewes than that in controls has previously reported by Nizamlioglu et al. (1989) and Nizamlioglu and Erganis (1991). Intramammary infection increases the permeability of microcirculatory vessels by secretion of various chemical mediators such as histamine, prostaglandin, kinins and free oxygen radicals from inflammatory cells (Honkanen-Buzalski and 
Sandham, 1981). So, changes in LDH and ALP activities might be suitable for early diagnosis of subclinical mastitis in ewes. The higher level of LDH in mastitic milk than blood serum LDH activity shows that blood serum was not the sole source of this enzyme in mastitic milk and it was probably also liberated from udder parenchymal cells and from disintegrated leucocytes (Michel, 1979; kitchen, 1981; Deianov, 1983; and Kato et al., 1989).

Finally it can be concluded that, subclinical mastitis was more prevalent in dairy ewes, staphylococci especially CNS were the most prevalent pathogen and CMT was useful as a screening test in ovine species but false positive results may occurred and so bacteriological culture must be done for accurate diagnosis. Moreover, LDH and ALP activities in milk might be an assisting tools for early diagnosis of intramammary infection in ewes.

\section{REFERENCES}

Ahmed, G.; Timms, L.L.; Morrical, L.D.G. and Brackelberg, P.O. (1992): Dynamics and significance of ovine subclinical intramammary infections and their effects on lamb performance. Sheep Res. 8: 25-29.

Albenzio, M.; Taibi, L.; Muscio, A. and Sevi, A. (2002): Prevalence and etiology of subclinical mastitis in intensively managed flocks and related changes in the yield and quality of ewe milk. Small Ruminant Research, 43: 219-226.

Al-Majali, A.M. and Jawabeh, S. (2003): Period prevalence and etiology of subclinical mastitis in Awassi sheep in Southern Jordan. Small Ruminant Research 2287: 1-6.

Ariznabarreta, A.; Gonzalo, C. and San primitivo, F. (2002): Microbiological quality and somatic cell count of ewe milk with special reference to staphylococci. J. Dairy Sci. 85: 1370-1375.

Baselga, R.; Albizu, I. and Amorena, B. (1994): Staphylococcus aureus paramecapsule and slime as virulence factors in ruminant mastitis. A review. Vet. Microbiol. 39 (3-4)195-204.

Batavani, R.A.; Mortaz, E.; Falahian, K. and Dowood., M.A. (2003): Study on frequency, etiology and some enzymatic activities of subclinical ovine mastitis in Urmia, Iran. Small Ruminant Research, 50: 45-50.

Bergmeyer, H.U. (1974): Methods of enzymatic Analysis, $2^{\text {nd }}$ Ed. Academic Press, London, pp. 574-582. 
Bergonier, D. and Berthelot, X. (2003): New advances in epizootiology and control of ewe mastitis. Livestock Production Science, 79: $1-16$

Bergonier, D.; Ranee de Crenoux, Rachel, R.; Gilles, L. and Xavier, B. (2003): Mastitis of dairy small ruminants. Vet. Res. 34: 689716.

Burriel, A.R. (1997): Dynamics of intramammary infection in the sheep caused by coagulase-negative staphylococci and its influence on udder tissue and milk composition, Vet. Rec. 140: 419-423.

Cruickshank, R.; Duguid, J.P.; Marmion, B.P. and Swan, R.H.A. (1975): Medical Microbiology (12 ${ }^{\text {th }}$ Ed.), Churchill livingstone, Edinburgh, London 587 pp.

Dario, C.; Laudadio, V.; Corsalini, T.; Bufiao, G. and Buonavoglia, C. (1996): Subclinical mastitis in sheep: occurrence/etiology and milk production in different genetic types Agricoltura Mediterranea, 126: 320-325.

De la cruz, M.; Serrano, E.; Montoro, V.; Marco, J.C.; Romeo, M.; Baslega, R.; Albizu, I. and Amorena, B. (1994): Etiology and prevalence of subclinical mastitis in the Mancehega sheep at mid-late lactation. Small Ruminant Research, 14: 175-180.

Deianov, M. (1983): LDH activity and isoenzyme spectrum in the leukocytes of cows with catarrhal mastitis and chronic endometritis. Vet. Med. Nauki. 20: 47-51.

Devriese, L.A.; Laevens, H.; Haesebrouck, F. and Hommez, J. (1994): A simple identification scheme for coagulase-negative staphylococci from bovine mastitis. Research Vet. Sci. 57: 240244.

Donovan, G.A.; Risco, C.A and Shearer, K. (1992): Assessment of the mammary system. Vet. Clin. North Am. Food Anim. Pract. 8: 361-372.

Fthenakis, G.C. (1994): Prevalence and etiology of subclinical mastitis in ewes of southern Greece. Small Ruminant Research, 13: 293300.

Fthenakis, G.C. (1996): Somatic cell counts in milk of WelshMountain, Dorset-Horn and Chios ewes throughout lactation. Small Ruminant Research, 20: 155-162.

Fthenakis, G.C. and Jones, J.E.T. (1990): The effect of experimentally induced subclinical mastitis on milk yield of ewes and on the growth of lambs. Br. Vet. J. 146: 43-49. 
Gonzalez-Rodriguez, C.M.; Gonzalo, C.; Primitivo, F.S. and Carmenes, P. (1995): Relationship between somatic cell count and intramammary infection of the half udder in dairy ewes. J. Dairy Sci. 78: 2753-2759.

Green, T.J. (1984): Use of somatic cell counts for detection of subclinical mastitis in ewes. Vet. Rec. 114: 43.

Gross, S.G.; Pollak, E.J.; Anderson, J.G. and Torell, D.T. (1978): Incidence and importance of subclinical mastitis in sheep. J. Anim. Sci. 46: 1-8.

Harmon, R.J. and Langlois, B.E. (1995): Mastitis due to coagulasenegative staphylococcus species, Proc. Annu. Mtg. Natl. Mastitis Counc., Fort Worth. Texas. Natl. Mastitis Counc., Inc., Arlington, Virginia, pp. 56-67.

Hogan, J.S.; White, D.G. and Pankey, J.W. (1987): Effects of teat dipping on intramammary infections by staphylococci other than Staphylococcus aureus. J. Dairy Sci. 70: 873-879.

Honkanen-Buzalski, T. and Sandham, M. (1981): Trypsin inhibitors in mastitic milk and colostrums: Correlation between trypsin inhibitor capacity, bovine serum albumin and somatic cell content. J. Dairy Res. 48: 213-233.

Jarp, J. (1991): Classification of coagulase-negative staphylococci isolated from bovine clinical and subclinical mastitis. Vet. Microbiol. 27: 151-158.

Kato, K.; Moir, K. and Katon, N. (1989): Contribution of Leukocyte origin of loctate dehydrogenase isozymes in milk of bovine mastitis. Nippon Juigaku Zasshi, 51: 530-539.

Keisler, D.H.; Andrew, M.L. and Moffat, R.J. (1992): Subclinical mastitis in ewes and its effect on lamb performance. J. Anim. Sci. 70: 1677-1681

Kirk, J.H. and Glenn, J.S. (1996): Mastitis in ewes. Compend. Contin. Educ. Pract. Vet. 18: 582-590.

Kirk, J.H.; Glee., J.S. and Maas, J.P. (1996): Mastitis in a flock of milking sheep. Small Ruminant Research, 22: 187-191.

Kitchen, B.J. (1981): Review of the progress of dairy science: bovine mastitis: milk compositional changes and related diagnostic tests. J. Dairy Res. 48: 167-188.

Kovac, J. and Beseda, I. (1975): Activity of lactate dehydrogenase in the milk serum of dairy cows in relation to the positive response to the mastitis NK-test. Vet. Med. Praha. 20: 483-487. 
Lafi, S.Q.; Al-Majali, A.M.; Rousan, M.D. and Al-Awneh, J.M. (1998): Epidemiological studies of clinical and subclinical ovine mastitis in Awassi sheep in northern Jordan. Preventive Veterinary Medicine, 33: 171-181.

Lafi, S.Q.; Al-Rawashdeh, O.F.; Ereifej, K.I. and Halat, N.Q. (1994):

Incidence of clinical mastitis and prevalence of subclinical udder infections in Jordanian dairy cattle. Prev. Vet. Med. 18: 89-98.

Langlois, B.E.; Parlindungan, A.K.; Hramon, R.J. and Akers, K. (1990): Biochemical characteristics of Staphylococcus species of human and bovine origin. J. Food Prot. 53:119-126.

Las Heras, A.; Domýnguez, L. and Fernandez, J. F. (1999): Prevalence and aetiology of subclinical mastitis in dairy ewes of the Madrid region. Small Ruminant Research, 32: 21-29

Maisi, P.; Junttila, J. and Seppanen, J. (1987): Detection of subclinical mastitis in ewes. Br. Vet. J. 143: 402-409.

Marco, J.C. (1994): Mastitis in Latxa ewes: epidemiology, diagnosis and control. Ph.D. Thesis, University of Zaragoza, Spain.

Mavrogenis, A.P.; Koumas, A.; kakoyiannis, C.K. and Taliotis, C.H. (1995): Use of somatic cell counts for the detection of subclinical mastitis in sheep. Small Ruminant Research, 17: 7884.

McCarthy, F.D.; Lyndsey, J.B.; Georand, M.T. and Notter, D.R. (1988): Incidence and control of subclinical mastitis in the intensively managed ewes. J. Anim. Sci. 66: 2715-2721.

McDougall, S.; Pankey, W.; Delaney, C; Barlow, J.; Patricia A.; Murdough, P.A. and Scruton, D. (2002): Prevalence and incidence of subclinical mastitis in goats and dairy ewes in Vermont, USA. Small Ruminant Research, 46: 115-121

Menzies, P.I. and Ramanoon, S.Z. (2001): Mastitis of sheep and goats. Vet. Clin. North Am. Food Anim. Pract. 17: 333-358.

Michel, G. (1979): Histochemical behavior of succinate dehydrogenase and lactate dehydrogenase as well as ribonucleic acid in the epithelium of lactic ducts and alveoli of cow udders. Arch. Exp. Vet. Med. 33: 745-751.

Moroni, P. and Cuccuru, C. (2001): Relationship between mammary gland infections and some milk immune parameters in Sardinian breed ewes. Small Ruminant Research, 41: 1-7. 
Nizamlioglu, M. and Erganis, O. (1991): Suitability of lactate dehydrogenase activity and some cell counts of milk for detection of subclinical mastitis in Merino ewes. Acta Veterinaria Hungarica, 39: 1-2.

Nizamlioglu, M.; Erganis, O.; Tekeli, T. and Baspinar, N. (1989): Some biochemical and microbiological studies on milk and blood for the early diagnosis of subclinical mastitis in sheep. Etlik Veteriner Microbioloji Dergisi, 6: 115-125.

Nobel, W.C. (1992): Staphylococci on the skin. In: W.C. Noble Editor, The Skin Microflora and Microbial Skin Disease, Cambridge University press, Cambridge, PP.15

Pednekar, U.V.T.; Swarup, D. and Srivastave, B.B. (1992): Evaluation of some indirect tests for detecting of subclinical mastitis. Indian J. Anim. Sci. 62: 1126-1130.

Peris, C.; Diaz, J.R.; Fernandez, N.; Radriguez, M. and Rubino, R. (1996): Effect of subclinical mastitis on milk yield of Manchega ewes: Preliminary results. In: Proceedings of Somatic Cells and Milk of Small Ruminants. EAAP Publication, Wageningen pers, wageningen, PP. 203-206.

Radostits, O.M.; Blood, D.C. and Gay, C.C. (2000): Veterinary Medicine: A Textbook of the Diseases of Cattle, Sheep, Pigs, Goats and Horses. $9^{\text {th }}$ ed. Saunders, Philadelphia.

Saratsis Ph.; Alexopoulosa, C.; Tzorab, A. and Fthenakisc, G.C. (1999):

The effect of experimentally induced subclinical mastitis on the milk yield of dairy ewes. Small Ruminant Research, 32: 205209.

Schalm, O.W.; Carrol, E.J. and Jain, N.C. (1971): Bovine Mastitis, Lea and Febiger, Philadelphia, USA, p. 360.

Snedecor, G.W. and Cochran, W.G. (1980): Statistical Methods. $8^{\text {th }}$ ed. the Iowa State, University Press, USA.

Stefanakis, A.; Boscos, C.; Alexopoulos, C. and and Samartzi, F., (1995): Frequency of subclinical mastitis and observation on somatic cell counts in ewes milk in Northern Greece. Anim. Sci. 61: 69-76.

Tietze, M.; Majewski, T. and Szmyanowska, A., (1993): Occurrence and prophylaxis of subclinical mastitis of sheep. In: Kukovics, S. (Ed.,) Proceedings of the Fifth International Symposium on Machine Milking of Small Ruminants. Budapest, Hungary, May 14-20, 1993, pp.121-126. 
Vieira-da-motta, M.; Folly, M. and Sakyiama, C.Ch. (2001): Detection of different Staphylococcus aureus strains in bovine milk from subclinical mastitis using PCR and routine techniques, Braz. J. Microbiol. 32: 27-31.

Waston, D.J. and Buswell, J.F. (1984): Modern aspects of mastitis. Br. Vet. J. 140: 529-534.

Watkins, G.H.; Burriel, R. and Jones, J.E.T. (1991): A field investigation of subclinical mastitis in sheep in Southern England. Br. Vet. J. 147: 413-420.

Winkler, A.B.M. and Gootwine, E. (1989): Non-clinical intramammary infection in lactating ewes and its association with clinical mastitis. Br. Vet. J. 145: 178-184. 